\title{
Effects of Five Years Adoption of No-Tillage Systems for Vegetables Crops in Soil Organic Matter Contents
}

\author{
Carlos E. P. Lima, ítalo M. R. Guedes, Juscimar da Silva, Flávia A. Alcântara, Nuno R. Madeira, \\ Agnaldo D. F. Carvalho, Mariana R. Fontenelle
}

Embrapa Hortaliças, CNPH, Brasília, Brazil

Email: carlos.pacheco-lima@embrapa.br

How to cite this paper: Lima, C.E.P., Guedes, í.M.R., da Silva, J., Alcântara, F.A., Madeira, N.R., Carvalho, A.D.F. and Fontenelle, M.R. (2018) Effects of Five Years Adoption of No-Tillage Systems for Vegetables Crops in Soil Organic Matter Contents. Agricultural Sciences, 9, 117-128. https://doi.org/10.4236/as.2018.91009

Received: November 25, 2017

Accepted: January 26, 2018

Published: January 29, 2018

Copyright (c) 2018 by authors and Scientific Research Publishing Inc. This work is licensed under the Creative Commons Attribution International License (CC BY 4.0).

http://creativecommons.org/licenses/by/4.0/ Open Access

\begin{abstract}
Vegetables productions systems are done normally with intense soil tillage causing a strong decline of soil quality. Use of conservation systems can be an alternative to recover this quality. In order to evaluate the effects of such systems on soil organic matter, an experiment has been conducted in randomized blocks design and factorial scheme $3 \times 2$ : three soil management systems (no-tillage; reduced tillage and conventional tillage) and two cover crops (maize single; and intercropping maize with gray velvet bean-Stizolobium niveum); and repeated measures over time. Soil samples were collected before the implementation of the experiment and at the end of each crop cycle until the fifth crop cycle. Carbon associated with humic substances is also determined in $0-5 \mathrm{~cm}, 5-10 \mathrm{~cm}$ and $10-30 \mathrm{~cm}$ at the end of the last crop cycle. The SOM content was higher in RT (48.34 $\left.\mathrm{g} \cdot \mathrm{kg}^{-1}\right)$ than in the CT $(39.48$ $\left.\mathrm{g} \cdot \mathrm{kg}^{-1}\right)$ at the end of the fifth crop cycle. SOM content in NT $\left(44.92 \mathrm{~g} \cdot \mathrm{kg}^{-1}\right)$ was statistically equal to RT and CT, during the same period. In $0-5 \mathrm{~cm}$, carbon contents associated to the humic substances present the same behavior of SOM contents in $0-10 \mathrm{~cm}$. Probably these results are associated with the capacity of each system to improve superficial contents of SOM stable fractions. It follows that the conservation systems used are alternatives to the cultivation vegetables in order to improve soil organic matter contents.
\end{abstract}

\section{Keywords}

No-Tillage, Reduced Tillage, Soil Conservation, Soil Management

\section{Introduction}

Soil management can improve carbon sequestration and makes this an impor- 
tant way to mitigate atmospheric greenhouse gases (GHG) emissions, principal responsible for global warming observed nowadays (Machado, 2005) [1]. However, soil degradation can significantly reduce their capacity to mitigate GHG emissions and also leads to an increase of GHG emissions from terrestrial environments. This process is closely associated to qualitative and quantitative loss of soil organic matter (SOM) due to the unsustainable use of soil (Johnson et al., 2007) [2]. Several studies in tropical soils have pointed to occurrence of drastically reduce of SOM as a result of non-conservation management system adoption (Souza et al., 2009; Figueiredo et al., 2010) [3] [4].

Vegetable production systems normally adopted in Brazil use intense soil tillage leading to a strong decline of soil quality. SOM can be understood as a key indicator of soil quality and changes in their quantity and quality have important impacts in many processes linked to agricultural and environmental sustainability as soil erosion, water infiltration and nutrients cycles (Franzluebbers, 2002) [5]. SOM is defined as the total soil biomass and substances resulting from the decomposition of terrestrial and aquatic plants, including peatlands (Dick et al., 2009) [6]. It can be divided into at least two groups related to their complexity and lability. Accordingly, there are less complex and labile SOM as organic acids with low molecular weight, carbohydrates, fats, waxes and proteins, and those more complex and non-labile as pyrogenic $\mathrm{C}$ and humic substances (HS). The latter, commonly represented by fulvic (FAC) and humic (HAC) acids, and by humin (HUMC) have chemical complexity increasing in that order and are determined by solubility in different $\mathrm{pH}$ conditions. The HS commonly constitute the major part of the SOM in tropical environments (Santos et al., 2013) [7] and present chemical composition that can affect the chemical, physical and biological soil properties. HS also have effect on the development of higher plants, on the carbon and nutrients cycles, and on the pollutants leaching [8].

Use of conservation systems in agriculture has partially reversed the tendency of soil degradation. SOM levels can increase when reduced tillage (RT) and no-tillage (NT) are adopted, especially if the soil had been managed conventionally before. The NT potential to improve carbon contents in tropical and subtropical soils have been reported by other studies (Conceição et al., 2013) [9]. In a vegetable production area of the Brazilian Cerrado, Souza et al. (2014) [10] also observed that the use of conservation systems improved the quantity and quality of SOM. However, there is little knowledge about the temporal dynamic of SOM contents in vegetables production areas when conservation systems are adopted, an important question to improve the sustainability of the agricultural soils. The studies cited previously show clearly the importance of addition of plant residues and reduced soil disturbance to increase both labile and no-labile SOM and thus increase $\mathrm{C}$ contents sustainably.

A relevant strategy for evaluation of temporal variation of a particular phenomenon is the conduction of experiments with repeated measures over time. At this point, it is important that a brief discussion should be done about such 
experiments. They present random effects (associated with experimental design) and fixed effects (associated with, for example, the soil samples collected over time), which often needs to use mixed models for data analysis. PROC MIXED is a Statistical Analysis System's (SAS) procedure that provides a flexible environment in which it is possible to model many types of data from experiments with repeated measures whether in time, space, or both, by using mixed models. Correlations among measures taken in the same experimental unit can be modeled using random effects, random regression coefficients and through specification of a covariance structure. PROC MIXED offers a wide range of usual covariance structures to model the covariation in time and space (Moser, 2016) [11], which makes them a good choice for analyzing data from experiments with repeated measures over time. The use of General Linear Models Procedure (GLM) sometimes can lead to erroneous and limited results because it does not allow to model the covariance structure of the data (Freitas et al., 2005) [12].

The present study aimed to understand the SOM contents variation over time in a Rhodic Ferralsol (FAO, 2015) [13] cultivated with vegetables using conservation systems during four crop cycles. It also aimed to evaluate the carbon contents associated with HS at the end of the last cycle and verify the existence of relations between their contents and those of SOM.

\section{Materials and Methods}

\subsection{Characterization of Experimental Area}

The experiment was conducted in Embrapa Vegetables experimental field, located in the rural zone of Gama-DF, with geographical coordinates $15^{\circ} 56^{\prime} \mathrm{S}$ and $48^{\circ} 0^{\prime} \mathrm{W}$ and altitude of $997.6 \mathrm{~m}$.

The local climate is Aw of Köppen classification (tropical savanna with rainfall concentration in summer). The annual average temperature and the total annual average rainfall of the period in which the experiment was conducted were, respectively, $22.92^{\circ} \mathrm{C}$ and $1516.4 \mathrm{~mm}$, according data measured in Embrapa Vegetables weather station.

The soil used could be classified as a Rhodic Ferralsol with clay silt texture whose chemical characteristics in the $0-20 \mathrm{~cm}$ layer determined prior to the experiment implementation are described as follows: $\mathrm{pH}-5.6$; $\mathrm{P}$ disponível-4.8 $\mathrm{mg} \cdot \mathrm{dm}^{-3} ; \mathrm{K}-170 \mathrm{mg} \cdot \mathrm{dm}^{-3} ; \mathrm{S}-45 \mathrm{mg} \cdot \mathrm{dm}^{-3} ; \mathrm{Ca}-10.3 \mathrm{cmol}_{\mathrm{c}} \cdot \mathrm{dm}^{-3} ; \mathrm{Mg}-3.6$ $\mathrm{cmol}_{c} \cdot \mathrm{dm}^{-3} ;$ Al trocável-0.0 $\mathrm{cmol}_{c} \cdot \mathrm{dm}^{-3} ; \mathrm{H}+\mathrm{Al}-5.8 \mathrm{cmol}_{c} \cdot \mathrm{dm}^{-3} ;$ MOS-25.3 $\mathrm{g} \cdot \mathrm{kg}^{-1}$.

\subsection{Experimental Design and Soil Management Systems}

It was conducted five crop cycles one per year, from 2008 to 2012. The original vegetation is grassland (Campo Sujo-Cerrado) and the area was used with vegetables conventional production systems since 1980s. The experiment was implemented in a completely randomized block design with four replications and 
factorial scheme $3 \times 2$ (three soil management systems and two cover plants). The soil management systems used are no-tillage (NT), reduced tillage (RT) and conventional tillage (CT), while the cover crops are maize (M) and intercropping maize (Zea mays) with gray velvet bean (Stizolobium niveum) (MM). The cover crops grown in the summer and the vegetable specie were planted in the winter of each year. Each experimental plot had $9 \mathrm{~m} \times 12 \mathrm{~m}$, covering an area of $108 \mathrm{~m}^{2}$.

In NT the soil was not plowed and just the opening of the planting lines or holes was performed. Straw was kept on surface in NT during all cultivation cycle. In RT, the straw was incorporated at subsurface (approximately $10 \mathrm{~cm}$ ) using a leveling disk harrow. Finally, in CT were used plowing and harrowing operations for soil management and straw was incorporated into deeper layer (approximately $20 \mathrm{~cm}$ ) than in RT. A brief history of vegetables and cover crops, as well as used fertilizations can be found below: first cycle-onion cultivation, fertilization at planting with $600 \mathrm{~kg} \cdot \mathrm{ha}^{-1}$ of NPK 04-30-16 and topdressing with $400 \mathrm{~kg} \cdot \mathrm{ha}^{-1}$ of ammonium sulfate; second cycle-cabbage cultivation, fertilization at planting with $1250 \mathrm{~kg} \cdot \mathrm{ha}^{-1}$ of triple superphosphate $+250 \mathrm{~kg} \cdot \mathrm{ha}^{-1}$ with ammonium sulfate and topdressing with $400 \mathrm{~kg} \cdot \mathrm{ha}^{-1}$ of ammonium sulfate; third cycle-broccoli cultivation, fertilization at planting with $1000 \mathrm{~kg} \cdot \mathrm{ha}^{-1}$ of triple superphosphate $+250 \mathrm{~kg} \cdot \mathrm{ha}^{-1}$ of ammonium sulfate and topdressing with 500 $\mathrm{kg} \cdot \mathrm{ha}^{-1}$ of ammonium sulfate; fourth cycle-pumpkin cultivation, fertilization at planting with $300 \mathrm{~kg} \cdot \mathrm{ha}^{-1}$ of simple superphosphate and topdressing with 150 $\mathrm{kg} \cdot \mathrm{ha}^{-1}$ of ammonium sulfate; fifth cycle-cabbage cultivation, fertilization at planting with $1000 \mathrm{~kg} \cdot \mathrm{ha}^{-1}$ with triple superphosphate $+250 \mathrm{~kg} \cdot \mathrm{ha}^{-1}$ ammonium sulfate and topdressing with $500 \mathrm{~kg} \cdot \mathrm{ha}^{-1}$ of ammonium sulfate. Soil correction with lime was carried out at the establishment of experiment.

The corn seeding was performed with spacing of $0.80 \mathrm{~m}$ and five seeds per linear meter. It was used a corrective fertilization using $100 \mathrm{~kg} \cdot \mathrm{ha}^{-1}$ of $\mathrm{P}_{2} \mathrm{O}_{5}$ and a commercial hybrid Ag 1051 Agroceres $^{\circledast}$, which was cultivated with a plant population of 55.000 plants $\cdot$ ha $^{-1}$. The gray velvet bean was seeded with spacing of $1.60 \mathrm{~m}$ and two seeds per meter, thirty days after seeded the maize, just in the experimental plots that used these cover crops. Straw were formed using a shredding, followed by the use of herbicides (Glyphosate and Paraquat).

\subsection{Cover Plants Biomass Sampling and Determination}

The cover crops biomass was sampled using a template (a frame with dimensions $1 \mathrm{~m} \times 1 \mathrm{~m}$ ) disposed on the soil surface at two different points of each experimental plot. Sampling was performed soon after rotary shredders and herbicide application.

All material present inside the template was collected and stored in plastic bags. After, it sent to the Soil Fertility and Plant Nutrition laboratory where it was dried at $65^{\circ} \mathrm{C}$ and subsequently their mass was determined using an analytical balance. 


\subsection{Soil Sampling and SOM Analysis}

Soil samples were collected at the end of each crop cycle at the $0-10 \mathrm{~cm}$ and $10-30 \mathrm{~cm}$ layers. Samples of the fourth crop cycle were not used because the experiment was severed damaged by a hailstorm. For soil sampling were opened four mini trenches per experimental plot where single soil samples were collected to form one composite soil sample. Samples were then stored in properly labeled plastic bags and subsequently led to the Soil Fertility and Plant Nutrition laboratory. They were then air dried, macerated and all material was sieved in a $2 \mathrm{~mm}$ sieve.

SOM contents were determined in soil samples collected per experimental plots at the end of each cultivation cycle. It was collected four simple samples to form one composite sample. In laboratory, the determination of total organic carbon (TOC) was performed by Walkley-Black method (Embrapa, 1997) [14]. SOM contents were determined multiplying TOC contents by 1,724 (van Bemmelen factor).

Samples collected for assessing the organic carbon (OC) content associated to HS were taken at the end of the fifth growing season, in the $0-5 \mathrm{~cm}, 5-10 \mathrm{~cm}$ and $10-30 \mathrm{~cm}$ layers. HS fractionation was performed by difference of solubility in different $\mathrm{pH}$ conditions and followed the method proposed by Benites et al. (2003) [15]. Finally, Carbon contents were determined by the Walkley-Black method (Embrapa, 2013) [14].

\subsection{Statistical Analysis}

SOM data were initially checked for normal distribution at $5 \%$ by Shapiro Wilk test. Later there was applied the Mauchly Sphericity test at 5\% to verify possible correlations between the samples taken in different cycles for each depth evaluated. When significant, the PROC MIXED provided by SAS ${ }^{\varpi}$ was used. Otherwise, when the test was not significant, it was used the PROC GLM, analyzing the data similarly to those obtained in split plot experiments.

When PROC MIXED was used, the covariance structure was selected using Akaike Information Criteria (AIC) (Akaike, 1973) [16]. The following structures were tested: Heterogeneous Autoregressive (1) (ARH 1), Heterogeneous Compound Symmetry (CSH), Compound Symmetry (CS), Autoregressive (1) (AR 1), Variance Components (VC), and Non-structured (UN). Then, the means were estimated by least squares and tested by Tukey-Kramer test at 5\%. In turn, in the cases in which the PROC GLM was used, the means were tested by Tukey test at $5 \%$.

The effects of tillage and cover crops, as well as the interactions among those factors on the HS carbon contents in the fifth cultivation cycle were verified by ANOVA by the application of $\mathrm{F}$ test and the means were tested by Tukey test at $5 \%$. Finally, the relationships among SOM and HS were established by the determination of Pearson's correlation coefficients. 


\section{Results and Discussion}

The sphericity test was significant only for the $10-30 \mathrm{~cm}$ layer $(\mathrm{P}<0.0001)$ requiring the analysis using the mixed procedure (PROC MIXED). Instead, the lack of significance observed for the SOM data determined for the $0-10 \mathrm{~cm}$ layer $(\mathrm{P}<0.3411)$ results in the analysis using PROC GLM. Use of univariate methods for analysis in repeated measures experiments is possible since the covariance matrix satisfies the sphericity or roundness conditions. The sphericity test assumes as null hypothesis that the covariance matrix to be tested is of spherical type. When non-significant at a given level, it is concluded that the covariance matrix is spherical and the data can be analyzed using univariate methods. On the contrary, if the sphericity test is significant the data must be analyzed in a multivariate analysis (Freitas et al., 2005) [12].

Use of PROC MIXED for the analysis of data concerning the SOM contents variation over time in the layer of $10-30 \mathrm{~cm}$ led to the need for application of AIC to set the best covariance structure. The AIC is originated from the minimizing of the Kullback-Leibler information (K-L), which can be considered as an estimate measurement between a real model and a candidate model. The estimate of K-L information in AIC is based on Log Likelihood function in its maximum point added of a penalty associated with the number of model parameters (Dal Bello, 2010) [17]. Among the tested structures, the CS was chosen due to the lower value of AIC presented. The calculated AIC values were: ARH1 -486.10; AR1-479.30; CSH-480.70; CS-476.70; VC-479.90; Un-491.70. According to Freitas et al. (2005) [12], the lowest values of AIC when they are positive means a best fit of the covariance structure to the data set.

Significant interaction between tillage systems and crop cycle can be observed for the SOM data originated from samples taken in the $0-10 \mathrm{~cm}$ layer. Already, just effect of the crop cycle on SOM contents are observed for the data concerning to the $10-30 \mathrm{~cm}$ layer.

SOM increments were observed for RT and NT over the period evaluated (Table 1). However, in CT, it was observed that the SOM contents increased only between the first and the second crop cycle and remained stable thereafter until the end of the study period. Despite this stability, SOM contents observed in CT calls attention by a strong reduction in their absolute values between the last and the second last crop cycle. Nevertheless, it is not possible to infer about a possible maintenance of this trend in subsequent periods.

Effects of different soil management systems on SOM contents were observed only in the last crop cycle. The highest SOM contents were observed for RT. The SOM contents found in NT were similar to RT and CT. Additionally, SOM contents observed in CT were lower than those found in RT. Already, SOM contents in the $10-30 \mathrm{~cm}$ layer increased over the evaluation period in the three soil management systems but it was not observed distinct effects of them in any year evaluated. 
Table 1. Soil organic matter variation in a Rodhic Ferralsol cultivated with vegetables in conservation systems.

\begin{tabular}{cccccc}
\hline $\begin{array}{c}\text { Management } \\
\text { systems }\end{array}$ & $\begin{array}{c}\text { Before the experiment } \\
\text { implementation }\end{array}$ & $\begin{array}{c}\text { Crop } \\
\text { cycle 1 }\end{array}$ & $\begin{array}{c}\text { Crop } \\
\text { cycle 2 }\end{array}$ & $\begin{array}{c}\text { Crop } \\
\text { cycle 3 }\end{array}$ & $\begin{array}{c}\text { Crop } \\
\text { cycle 5 }\end{array}$ \\
\hline NT & $28.82 \mathrm{aC}$ & $39.03 \mathrm{aB}$ & $41.52 \mathrm{aAB}$ & $44.64 \mathrm{aA}$ & $44.92 \mathrm{abA}$ \\
RT & $28.82 \mathrm{aD}$ & $37.61 \mathrm{aC}$ & $41.71 \mathrm{aBC}$ & $43.67 \mathrm{aB}$ & $48.34 \mathrm{aA}$ \\
CT & $28.82 \mathrm{aB}$ & $37.61 \mathrm{aA}$ & $40.52 \mathrm{aA}$ & $43.26 \mathrm{aA}$ & $39.48 \mathrm{bA}$ \\
& & $10-30 \mathrm{~cm}\left(\mathrm{~g} \cdot \mathrm{kg}^{-1}\right)$ & & \\
NT & $20.75 \mathrm{aC}$ & $32.54 \mathrm{aB}$ & $30.50 \mathrm{aB}$ & $32.17 \mathrm{aAB}$ & $36.23 \mathrm{aA}$ \\
RT & $20.75 \mathrm{aC}$ & $29.99 \mathrm{aB}$ & $29.06 \mathrm{aB}$ & $31.57 \mathrm{aB}$ & $36.55 \mathrm{aA}$ \\
CT & $20.75 \mathrm{aC}$ & $29.23 \mathrm{aB}$ & $31.08 \mathrm{aB}$ & $33.40 \mathrm{aAB}$ & $35.60 \mathrm{aA}$ \\
\hline
\end{tabular}

NT-No-tillage; RT-Reduced tillage; CT-Conventional tillage. Means followed by the same small letters (columns) and capital letters (line) are not different by Tukey test $(0-10 \mathrm{~cm})$ or Tukey-Kramer test $(10-30$ $\mathrm{cm})(\mathrm{P}<0.05)$.

Zikeli et al. (2013) [18] showed that the reduction of intensity and depth of tillage improves SOM contents in a Germany Luvisol. Use of NT resulted in positive effects on SOM in subtropical and tropical soils (Conceição et al., 2013) [9]. Frequently has been cited in literature that NT normally maintain higher superficial SOM contents than RT, especially in long-term experiments (Prasad et al., 2016) [19]. It was possible that, in the present study, the time of adoption of the systems has not been enough for the NT show its full potential to improve SOM contents.

The carbon contents associated to the HS were determined in samples collected at the end of the last crop cycle (Table 2). Means of organic carbon associated to the HS in the $0-5 \mathrm{~cm}$ layer presents similar behavior to those of SOM contents quantified in the $0-10$ layer, as discussed in the preceding paragraphs. Thus, it is possible to infer that there is a possible positive relationship between the accumulation of stable fractions as HS and the observed SOM accumulation in superficial layers. No effects of management systems on SOM and HS contents in the deeper layers $(5-10 \mathrm{~cm}$ and $10-30 \mathrm{~cm})$ were found. There were also no observed effects of cover crops on carbon contents associated to the HS in any layer evaluated.

Positive relationship between TOC contents and the $\mathrm{C}$ contents associated to the HS in the $0-5 \mathrm{~cm}$ layer can be confirmed by Pearson Correlation Coefficients $(\mathrm{FAC}$ and $\mathrm{TOC}=0.92 ; \mathrm{HAC}$ and $\mathrm{TOC}=0.93 ; \mathrm{HUMC}$ and $\mathrm{TOC}=0.87$ ) (Table 3). Concomitant occurrence of higher HS and TOC contents in subtropical and tropical soils is a well-documented fact as can be exemplified by the study of Ebeling et al. (2011) [20].

It was observed a predominance of HUMC in comparison with the others HS in all layers, as can be shown by the EAC:HUMC relationship lesser than zero. 
Table 2. Carbon associated to the humic substances in a Rhodic Ferralsol cultivated with vegetables, in conservation systems, after five crop cycles.

\begin{tabular}{|c|c|c|c|c|c|c|}
\hline & TOC $\left(\mathrm{g} \cdot \mathrm{kg}^{-1}\right)$ & $\mathrm{HAC}\left(\mathrm{g} \cdot \mathrm{kg}^{-1}\right)$ & FAC $\left(g \cdot \mathrm{kg}^{-1}\right)$ & HUMC $\left(\mathrm{g} \cdot \mathrm{kg}^{-1}\right)$ & HAC:FAC & EAC:HUMC \\
\hline \multicolumn{7}{|c|}{$0-5 \mathrm{~cm}$} \\
\hline \multicolumn{7}{|c|}{ Soil management systems } \\
\hline NT & $27.52 \mathrm{~b}$ & $3.57 \mathrm{ab}$ & $7.24 \mathrm{ab}$ & $12.22 \mathrm{ab}$ & 0.49 & 0.88 \\
\hline RT & $31.29 \mathrm{a}$ & $4.28 \mathrm{a}$ & $7.66 \mathrm{a}$ & $13.27 \mathrm{a}$ & 0.56 & 0.90 \\
\hline CT & $23.84 \mathrm{c}$ & $2.46 \mathrm{~b}$ & $6.31 \mathrm{~b}$ & $11.48 \mathrm{~b}$ & 0.40 & 0.76 \\
\hline \multicolumn{7}{|c|}{ Cover crops } \\
\hline $\mathrm{M}$ & $27.73^{\text {ns }}$ & $3.76^{\mathrm{ns}}$ & $7.16^{\mathrm{ns}}$ & $12.58^{\mathrm{ns}}$ & 0.53 & 0.87 \\
\hline MM & $26.68^{\text {ns }}$ & $3.11^{\mathrm{ns}}$ & $6.98^{\text {ns }}$ & $12.07^{\mathrm{ns}}$ & 0.46 & 0.84 \\
\hline \multicolumn{7}{|c|}{$5-10 \mathrm{~cm}$} \\
\hline \multicolumn{7}{|c|}{ Soil management systems } \\
\hline NT & $23.64^{\mathrm{ns}}$ & $4.43^{\mathrm{ns}}$ & $5.30^{\mathrm{ns}}$ & $9.86^{\mathrm{ns}}$ & 0.84 & 0.99 \\
\hline RT & $23.64^{\mathrm{ns}}$ & $3.82^{\mathrm{ns}}$ & $5.13^{\text {ns }}$ & $10.74^{\mathrm{ns}}$ & 0.74 & 0.83 \\
\hline CT & $24.01^{\mathrm{ns}}$ & $4.19^{\mathrm{ns}}$ & $4.87^{\mathrm{ns}}$ & $10.14^{\mathrm{ns}}$ & 0.86 & 0.89 \\
\hline \multicolumn{7}{|c|}{ Cover crops } \\
\hline M & $24.14^{\mathrm{ns}}$ & $4.21^{\mathrm{ns}}$ & $5.13^{\text {ns }}$ & $10.33^{\mathrm{ns}}$ & 0.82 & 0.90 \\
\hline MM & $23.39^{\text {ns }}$ & $4.08^{\mathrm{ns}}$ & $5.07^{\mathrm{ns}}$ & $10.16^{\mathrm{ns}}$ & 0.80 & 0.90 \\
\hline \multicolumn{7}{|c|}{$10-30 \mathrm{~cm}$} \\
\hline \multicolumn{7}{|c|}{ Soil management systems } \\
\hline NT & $21.02^{\mathrm{ns}}$ & $4.54^{\mathrm{ns}}$ & $3.60^{\mathrm{ns}}$ & $9.79^{\text {ns }}$ & 1.26 & 0.83 \\
\hline $\mathrm{RT}$ & $21.20^{\mathrm{ns}}$ & $3.99^{\text {ns }}$ & $3.78^{\text {ns }}$ & $9.58^{\mathrm{ns}}$ & 1.06 & 0.81 \\
\hline CT & $20.65^{\mathrm{ns}}$ & $4.10^{\mathrm{ns}}$ & $3.38^{\mathrm{ns}}$ & $9.44^{\mathrm{ns}}$ & 1.21 & 0.79 \\
\hline \multicolumn{7}{|c|}{ Cover crops } \\
\hline $\mathrm{M}$ & $20.52^{\mathrm{ns}}$ & $4.28^{\mathrm{ns}}$ & $3.61^{\mathrm{ns}}$ & $9.60^{\mathrm{ns}}$ & 1.19 & 0.82 \\
\hline MM & $21.39^{\mathrm{ns}}$ & $4.14^{\mathrm{ns}}$ & $3.56^{\mathrm{ns}}$ & $9.60^{\text {ns }}$ & 1.16 & 0.80 \\
\hline
\end{tabular}

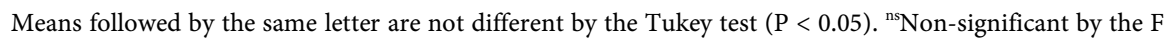
test $(\mathrm{P}<0.05)$.

Table 3. Pearson correlation coefficients between total organic carbon and carbon associated to the humic substances contents in a Rhodic Ferralsol cultivated with vegetables, in conservation systems.

\begin{tabular}{cccc}
\hline & FAC & HAC & HUMC \\
\hline TOC $(0-5 \mathrm{~cm})$ & $0.92^{\star}$ & $0.93^{\star}$ & $0.87^{\star}$ \\
TOC $(5-10 \mathrm{~cm})$ & $-0.20^{\mathrm{ns}}$ & $-0.13^{\mathrm{ns}}$ & $0.09^{\mathrm{ns}}$ \\
TOC $(10-30 \mathrm{~cm})$ & $-0.59^{\mathrm{ns}}$ & $-0.08^{\mathrm{ns}}$ & $0.05^{\mathrm{ns}}$
\end{tabular}

*significant $(\mathrm{P}<0.05)$; ${ }^{\text {ns }}$ Non-significant $(\mathrm{P}<0.05)$; TOC-Total Organic Carbon; FAC-carbon associated to the fulvic acids; HAC_carbon associated to the humic acids; HUMC_carbon associated to the humin. 
Also, it was quantified higher contents of FAC than HAC in the 0 - 5 and $5-10$ $\mathrm{cm}$ layers. Predominance of HUMC in subtropical and tropical soils has been strongly reported in scientific literature, as done by Brancalião \& Moraes (2008) [21]. These authors also reported the predominance of FAC when compared with HAC in a Rhodic Nitisol cultivated with soybean under different soil and cover crops biomass management systems. Bezerra et al. (2013) [22] checking the effects of integration-crop-livestock-forest and no-tillage systems on the soil organic matter of a Rhodic Ferralsol in Brazilian Cerrado found contents and behavior of HS similar to those reported in the present study.

It is possible that the higher TOC contents observed in RT may be linked with the reduction of soil tillage and the faster straw decomposition in relation to NT. In the latter case, the subsurface incorporation of cover crops biomass leads to acceleration of decomposition processes (Carvalho et al., 2008) [23]. It was observed a similar (no statistical significance at $5 \%$ ) initial dry biomass production for all soil management systems and cover crops, as follow: NT-1069.63 g; RT-810.88 g; CT-938.00 g; M-933.25 g; MM-945.75 g. Them, the faster decomposition of plant residues associated with low disturbance in RT could lead to an acceleration of HS formation and therefore increase the presence of stable organic matter and consequently the TOC contents. It is worth noting that the incorporation of cover crops biomass in RT was done by leveling disk harrow at subsurface (approximately $10 \mathrm{~cm}$ ), just where the effects of management systems on TOC and HS were noticed. The degradation of organic residues is an important step for the activation of the main routes of HS formation and it is also essential for the supramolecular arrangements formation (Piccolo, 2002) [24].

There are doubts, however, about the long-term sustainability of RT to maintain higher TOC contents than the NT, as indicated by results of other studies such as those of Prasad et al. (2016) [19]. It is possible that in NT the absence of cover crops incorporation leads to a more gradual increase of SOM and HS contents than in RT, resulting in lower contents in short and medium term experiments. In different edaphoclimatic conditions, Zhang et al. (2016) [25] showed that the full capacity of NT to accumulate soil carbon is reached in about ten years after its adoption, especially when the soil was previously in agricultural use with conventional systems. Thus, it is possible that the maturity of the NT has not been reached in the present study. However, it is worth mentioning that the vegetable production systems present important peculiarities as high fertilization rates and lower commercial species biomass production that can lead to different behavior of SOM and its fractions. Thus, it becomes clear that there is need for further studies to understand SOM dynamics in vegetables conservation systems.

Finally, it should be noted that the CT promoted a strong initial increase of SOM contents. This result is different from those commonly found in other studies and previously cited in this paper. It is possible that this fact is due to the 
incorporation of a great quantity of cover crops biomass.

\section{Conclusions}

Conservation soil management systems increased initial SOM contents in both $0-10 \mathrm{~cm}$ and $10-30 \mathrm{~cm}$ layers.

At the end of the last crop cycle, the RT and the NT improved more efficiently the SOM contents in the $0-10$ m layer.

RT maintained the higher TOC contents in the $0-5 \mathrm{~cm}$ layer, probably associated with the high contents of HS.

\section{References}

[1] Machado, P.L.O.A. (2005) Soil Carbon and the Mitigation of Global Climate Change. Química Nova, 28, 329-334. https://doi.org/10.1590/S0100-40422005000200026

[2] Johnson, J.M.F., Franzluebbers, A.J., Weyers, S.L. and Reicoski, D.C. (2007) Agricultural Opportunities to Mitigate Greenhouse Gas Emissions: A Review. Environmental Pollution, 150, 107-124. https://doi.org/10.1016/j.envpol.2007.06.030

[3] Souza, E.D., Costa, S.E.V.G.A., Anghinoni, I., Carvalho, P.C., Andrigueti, M. and Cao, E. (2009) Soil Organic Carbon and Nitrogen Stocks in an Untilled Crop-Livestock Integration System under Different Grazing Intensities. Revista Brasileira de Ciência do Solo, 33, 1829-1836. https://doi.org/10.1590/S0100-06832009000600031

[4] Figueiredo, C.C., Resck, D.V.S. and Carneiro, M.A.C. (2010) Labile and Stable Fractions of Soil Organic Matter under Management Systems and Native Cerrado. Revista Brasileira de Ciência do Solo, 34, 907-916. https://doi.org/10.1590/S0100-06832010000300032

[5] Franzluebbers, A.J. (2002) Soil Organic Matter Stratification Ratio as an Indicator of Soil Quality. Soil \& Tillage Research, 66, 95-106. https://doi.org/10.1016/S0167-1987(02)00018-1

[6] Dick, D.P., Novotny, E.H., Dieckow, J. and Bayer, C. (2009) Chemistry of Soil Organic Matter: In: Melo, V.F. and Alleoni, L.R., Eds., Química e Mineralogia do Solo: Parte II-Aplicações, Sociedade brasileira de Ciência do Solo, Viçosa, 1-68.

[7] Santos, L.L., Lacerda, J.J. and Zinn, Y.L. (2013) Partitioning of Humic Substances in Brazilian Soils. Revista Brasileira de Ciência do Solo, 37, 955-968.

https://doi.org/10.1590/S0100-06832013000400013

[8] Bayer, C, Kick, D.P., Ribeiro, G.M. and Scheuermann, K.K. (2002) Carbon Stocks in Organic Matter Fractions as Affected by Land Use and Soil Management with Emphasis on No-Tillage Effect. Ciência Rural, 32, 401-406.

https://doi.org/10.1590/S0103-84782002000300006

[9] Conceição, P.C., Dieckow, J. and Bayer, C. (2013) Combined Role of No-Tillage and Cropping Systems in Soil Carbon Stocks and Stabilization. Soil \& Tillage Research, 129, 40-47. https://doi.org/10.1016/j.still.2013.01.006

[10] Souza, R.F., Figueiredo, C.C., Madeira, N.R. and Alcântara, F.A. (2014) Effect of Management Systems and Cover Crops on Organic Matter Dynamics of Soil under Vegetables. Revista Brasileira de Ciência do Solo, 38, 923-933. https://doi.org/10.1590/S0100-06832014000300024 
[11] Moser, E. (2016) Repeated Measures Modeling with PROC MIXED. http://www2.sas.com/proceedings/sugi29/188-29.pdf

[12] Freitas, A.R.F., Presotti, C.V. and Toral, F.L.B. (2005) Alternative Analyses of Repeated Weight Measurements of Beef Cattle. Revista Brasileira de Zootecnia, 34, 2233-2244. https://doi.org/10.1590/S1516-35982005000700010

[13] FAO (2015) World Reference Base for Soil Resources 2014: International Soil Classification System for Naming Soils and Creating Legends for Soil Maps. FAO, Roma.

[14] Empresa Brasileira De Pesquisa Agropecu ÁRIA-Embrapa. (2013) Manual of Methods of Soil Analysis. Rio de Janeiro.

[15] Benites, V.M., Madari, B. and Machado, P.L.O.A. (2003) Extraction and Fractionation of Soil Humic Substances: A Simplified Low Cost Procedure. Comunicado Técnico.

http://ainfo.cnptia.embrapa.br/digital/bitstream/CNPS/11578/1/comtec16_2003_ext racao.pdf

[16] Akaike, H. (1973) Information Theory and an Extension of the Maximum Likelihood Principle. In: International Symposium on Information Theory, Vol. 2, Anais Academiai Kiado, Budapest, 267-281.

[17] Dal Bello, L.H.A. (2010) Modeling in Experiments Mixing-Process for Optimization of Industrial Processes. PhD Dissertation, PUC-RJ, Rio de Janeiro.

[18] Zikeli, S., Gruber, S., Teufel, C.F., Hartung, K. and Claupein, W. (2013) Effects of Reduced Tillage on Crop Yield; Plant Available Nutrients and Soil Organic Matter in a 12-Year Long-Term Trial under Organic Management. Sustainability, 5, 3876-3894. https://doi.org/10.3390/su5093876

[19] Prasad, J.V.N.S., Rao, C.S., Srinivas, K., Jyothi, C.N., Venkateswarlu, B., Ramachandrappa, B.K., Dhanapal, G.N., Ravichandra, K. and Mishra, P.K. (2016) Effect of Ten Years of Reduced Tillage and Recycling of Organic Matter on Crop Yields; Soil Organic Carbon and Its Fractions in Alfisols of Semi Arid Tropics of Southern India. Soil \& Tillage Research, 156, 131-139. https://doi.org/10.1016/j.still.2015.10.013

[20] Ebeling, A.G., Anjos, L.H.C., Pereira, M.G., Pinheiro, E.F.M. and Valladares, G.S. (2011) Humic Substances and Relationship to Soil Attributes. Bragantia, 70, 157-165. https://doi.org/10.1590/S0006-87052011000100022

[21] Brancalião, S.R. and Moraes, M.H. (2008) Changes in Some Physical Properties and in Humic Fractions of a Nitosol Cropped with a Millet-Soybean Sucession under No-Tillage. Revista Brasileira de Ciência do Solo, 32, 393-404. https://doi.org/10.1590/S0100-06832008000100037

[22] Bezerra, R.P.M., Loss, A., Pereira, M.G. and Perin, A. (2013) Forms of Carbono in $\mathrm{Na}$ Oxisol under No-Tillage and Crop-Livestock Integration Systems in the Cerrado, Goias State, Brazil. Semina, 34, 2637-2654.

[23] Carvalho, A.M., Bustamante, M.M.C., Sousa Junior, J.G.A. and Vivaldi, L.J. (2008) Decomposition of Plant Residues in Latosol under Corn Crop and Cover Crops. Revista Brasileira de Ciência do Solo, 32, 2831-2838. https://doi.org/10.1590/S0100-06832008000700029

[24] Piccolo, A. (2002) The Supramolecular Structure of Humic Substances: A Novel Understanding of Húmus Chemistry and Implications in Soil Science. Advances in Agronomy, 75, 57-134. https://doi.org/10.1016/S0065-2113(02)75003-7

[25] Zhang, Z., Hongjun, Q., Mchugh, A.D., Li, H., Wang, Q. and Lu, Z. (2016) Effect of 
Conservation Farming Practices on Soil Organic Matter and Stratification in a Mono-Cropping System of Northern China. Soil \& Tillage Research, 156, 173-181. https://doi.org/10.1016/j.still.2015.10.008 